\title{
鉄筋とコンクリート棒形振動機の接触を考慮したコンクリートの 締固めにおける再振動に関する一考察 \\ INVESTIGATION OF REVIBRATING CONDITIONS WHEN DEFORMED BARS ARE IN CONTACT WITH INTERNAL VIBRATOR
}

\author{
中田善久*, 大塚秀三**, 宮田敦典***, 新 妻 尚 祐**** \\ Yoshihisa NAKATA, Shuzo OTSUKA, Atsunori MIYATA \\ and Naohiro NIITUMA
}

\begin{abstract}
The purpose of this study is to obtain appropriate conditions of concrete revibration when placing on the consolidated fresh concrete. In this experimental study, the effect of revibrating conditions on compressive and bond strength were investigated. Parameters included timing from mixing to revibrating, duration of revibrating, distance of revibrating point and duration of contact between deformed bar and internal vibrator. As a result, compressive and bond strength of revibrated specimens showed an increase when timing from mixing to revibrating increased. But bond strength of revibrated specimens with deformed bar in contact with internal vibrator showed a decrease when timing from mixing to revibrating and duration of the contact increased. This paper also proposed an appropriate method of revibrating when placing on the consolidated fresh concrete on the basis of the experimental results.
\end{abstract}

Keywords: Revibrating, Compaction, Concrete, Steel Deformed Bar, Internal Vibrator, Contact 再振動, 締固め, コンクリート, 異形鉄筋, コンクリート棒形振動機, 接触

\section{1.はじめに}

構造体コンクリートの品質は、コンクリート工事における運搬, 打込みおよび締固めの一連の作業の良否により大きく左右されるこ とは言うまでもない。日本建築学会「建築工事標準仕様書・同解説 JASS 5 鉄筋コンクリート工事 2009」 ${ }^{1)}$ (以下、JASS 5 という) の 7 節「コンクリートの運搬・打込みおよび締固め」において、施工に 関寸る重要な事項が記述されている。この中で、コンクリートの運 搬において「コンクリートの練混ぜから打込み終了の時間の限度は、 外気温が $25^{\circ} \mathrm{C}$ 未満のときは 120 分、 $25^{\circ} \mathrm{C}$ 以上のときは 90 分とする。」 と記述され、打込みにおいて「打重衫時間間隔の限度は、コールド ジョイントが生じない範囲として定め、工事監理者の承認を受け る。」と記述されている。また、打重㸚時間間隔の限度は、「一律に 定めることはできないが、一般的には、外気温が $25{ }^{\circ} \mathrm{C}$ 未満のとき は 150 分、 $25^{\circ} \mathrm{C}$ 以上のとま 120 分を目安とし、先に打ち込んだコ ンクリートの再振動可能時間以内と寸る。と解説されている。さ らに、締固めにおいて「公称棒形 $45 \mathrm{~mm}$ の棒形振動機の長さは 60 $80 \mathrm{~cm}$ であるので、1 層の打込み厚さはそれ以下にする。振動機の先 端を先に打ち込んだコンクリートの層に入れるのは、コールドジョ イントを防止するためである。」と解説されている。一方、土木学 会「2007 年制定 コンクリート標準示方書 [施工編：標準施工］2) の 7 章「運搬・打込み・締固めおよび仕上げ」にも、JASS 5 と同
様な事項が記述されている他に、「再振動を行なう場合には、コン クリートの締固めが可能な範囲でできるだけ遅い時期がよい。」と 記述されている。このように、コンクリートの締固めにおける再振 動は、一般的に、コールドジョイント防止を目的として再振動可能 時間以内（できるだけ遅い時期）に行なうこととなっている。

棒形振動機による締固めの要領として JASS $5{ }^{11}$ に「振動機の先 端は、鉄骨・鉄筋・埋込み配管・金物・型枠などになるべく接触さ せない。」と解説されており、これは、配筋や型枠などの乱れを防 止する意味である。しかし、梁や壁などのように比較的小さい部材 のときに配筋が過密となり、施工上、鉄筋とコンクリート棒形振動 機の接触は避けにくい状況がある。特に、打重ね部分において再振 動を行うときにこの接触状況が更に厳しくなり、このことが構造体 コンクリートの品質に及ぼす影響について検討された既往の研究は、 見当らない。

そこで、本研究は、コンクリートの再振動における鉄筋とコンク リート棒形振動機の接触が構造体コンクリートの品質および異形鉄 筋の付着性状に及ぼす影響を明らかにし、さらに、最適な再振動の 施工要領を考察するために行ったものである。ここでは、再振動に おける振動の有無が圧縮強度に及ぼす影響, 再振動における振動距 離と振動時間が異形鉄筋の付着性状に及ぼす影響および再振動にお けるコンクリート棒形振動機と鉄筋の接触が異形鉄笳の付着性状に
* 日本大学理工学部建築学科 教授 · 博士 (工学)

**ものつくり大学技能工芸学部建設学科 准教授·博士 (工学)

*** 日本大学理工学部建築学科 助手. 修士 (工学)

**** 新妻鋼業 代表取締役社長
Prof., Dept. of Architecture, College of Science and Technology, Nihon University, Dr. Eng. Assoc. Prof., Dept. of Building Technologists, Monotsukuri Institute of Technologists, Dr. Eng.

Research Assist., Dept. of Architecture, College of Science and Technology, Nihon University, M. Eng.

NIIDUMA KOGYO CO., LTD. 


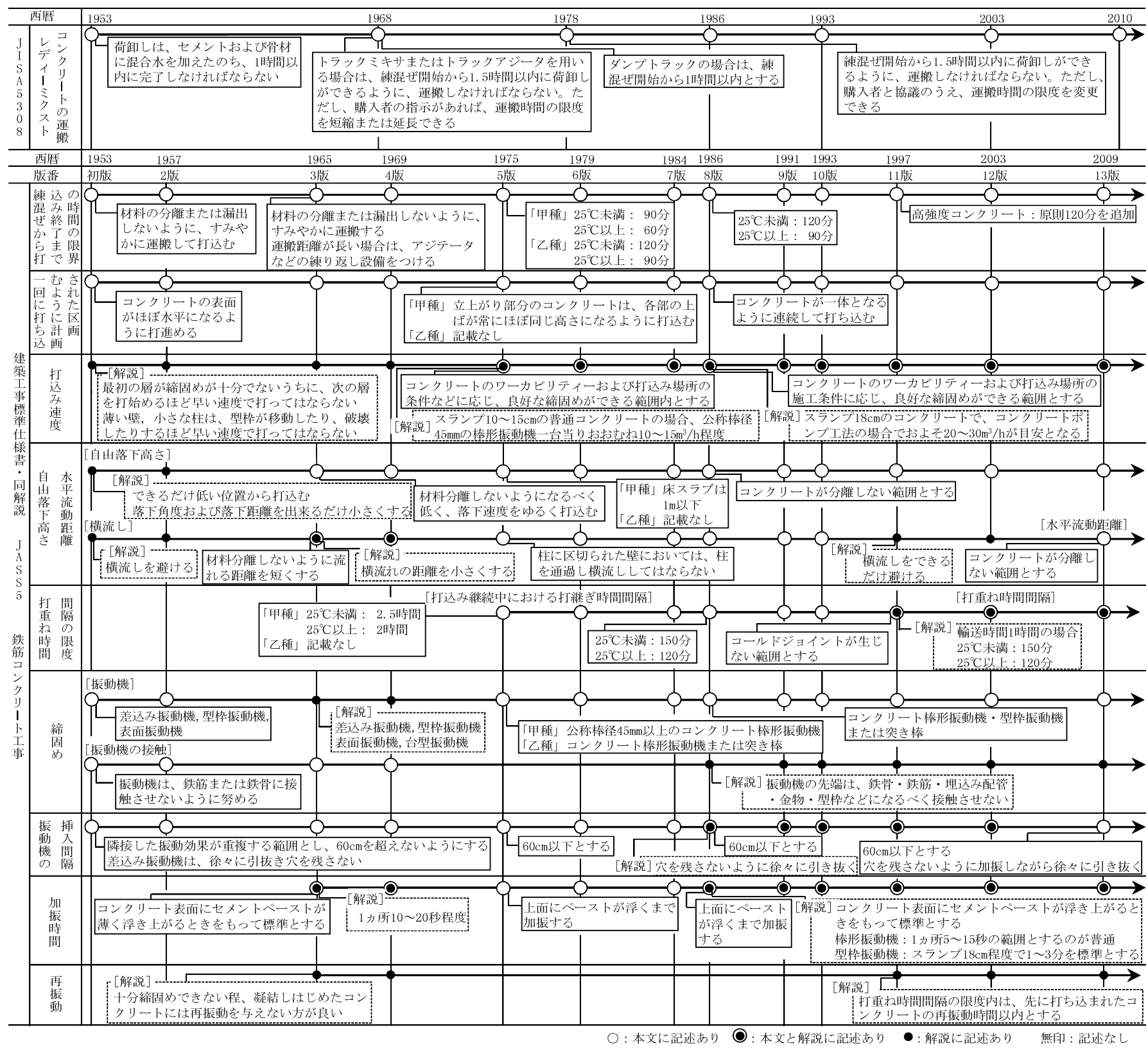

図 1 JIS A $5308^{5)}$ における運搬時間およびJASS 5 における運搬・打込み・締固めの仕様の変遷

及ぼす影響について検討したものである。

本論文は、これまでに報告 ${ }^{3)}$ ，4)したものに加筆検討し、とりまと めたものである。

\section{2. 締固めにおける再振動に関する既往の研究と本研究の関係}

JIS A $5308^{5)}$ における運搬時間およびJASS 5 における運搬・打 込み・締固めの仕椂の変遷を図 1 に示寸。この中で、「レディーミ クストコンクリート」は、1953 年にJIS A 53085) として制定され、 1968 年に「運搬時間が練混ぜ開始から 1.5 時間以内に荷卸しできる ように運搬しなければならない。と改正された。一方、コンクリー 卜工事は、1960 年代に入ると第 2 次機械化と施工技術の合理化急 速化 ${ }^{6)}$ が進み、工事の全部にレディーミクストコンクリートの採用 率が急激に増加していく。このような背景から 1975 年の JASS 5 の 改定において「練混ぜから打込夕終了までの時間の限界」に具体的
な時間が記述され、さらに、「打込み継続中における打継ぎ時間間 隔（現在の打重衩時間間隔である。）」も具体的な時間が記述され た。また、締固めにおける再振動は、1965 年の JASS 5 の改定にお いて「凝結しはじめたコンクリートには再振動を与えない方が良 い」と解説され、この他に、「 3 時間内外で前のコンクリートへの 打継ぎ目では $3 \sim 4 \mathrm{~cm}$ 前のコンクリートも再振動することは継目の 切目をなくし一体コンクリートの役立つ」と経験的な解説であり、 コンクリートのコールドジョイントの側面からのものと考えられ る。さらに、初版から締固めに用いる振動機の接触は、「鉄筋また は鉄骨に接触しないように努める。」ことが記述されており、JASS 5 制定当初からこの重要性が問われてきた。

この締固めにおける再振動の研究として、Vo11ick C.A 7)が代表 的であり、コンクリート棒形振動機を用いて再振動までの時間を 1 $\sim 4$ 時間と変えた場合、打込み後 $1 \sim 2$ 時間で圧縮強度が $13.8 \%$ 程 

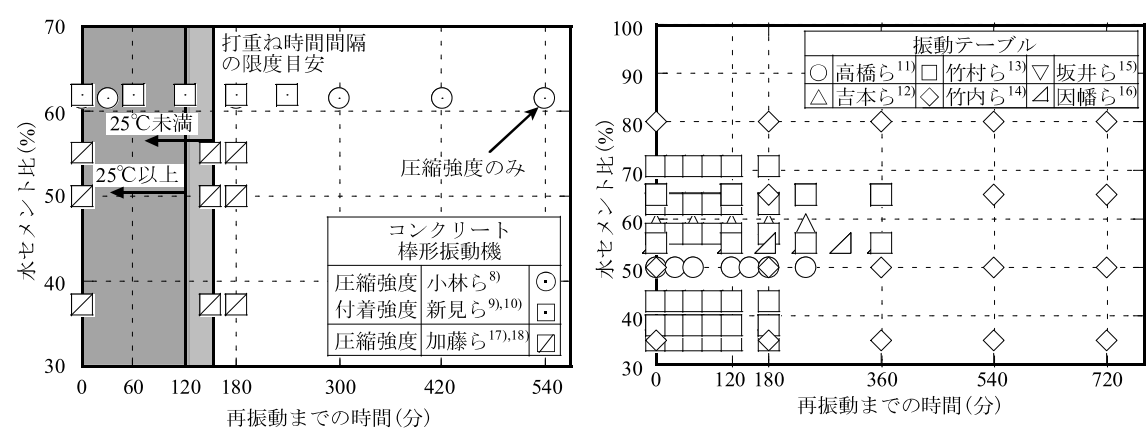

図 2 既往の研究 ${ }^{8) ~}{ }^{18)}$ における再振動までの時間と水セメント比の関係
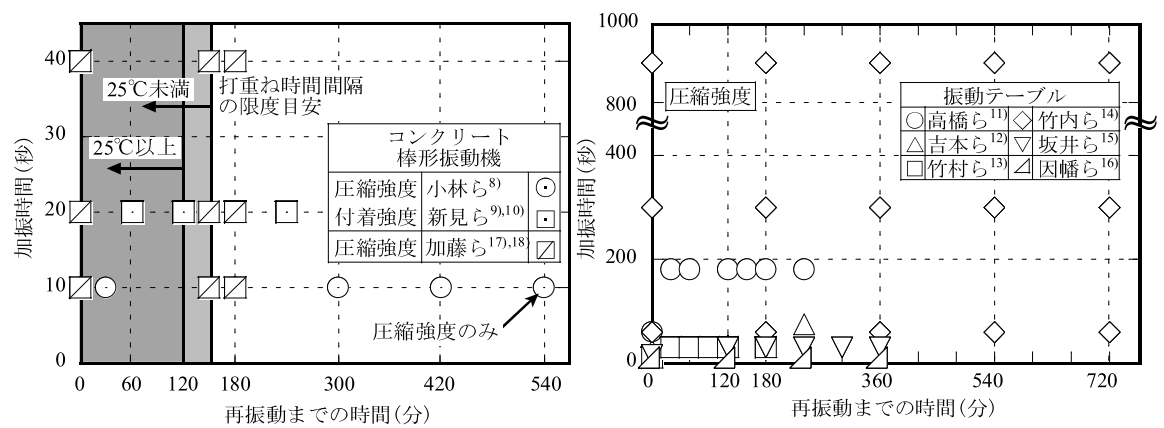

図 3 既往の研究 8) 18)における再振動までの時間と加振時間の関係
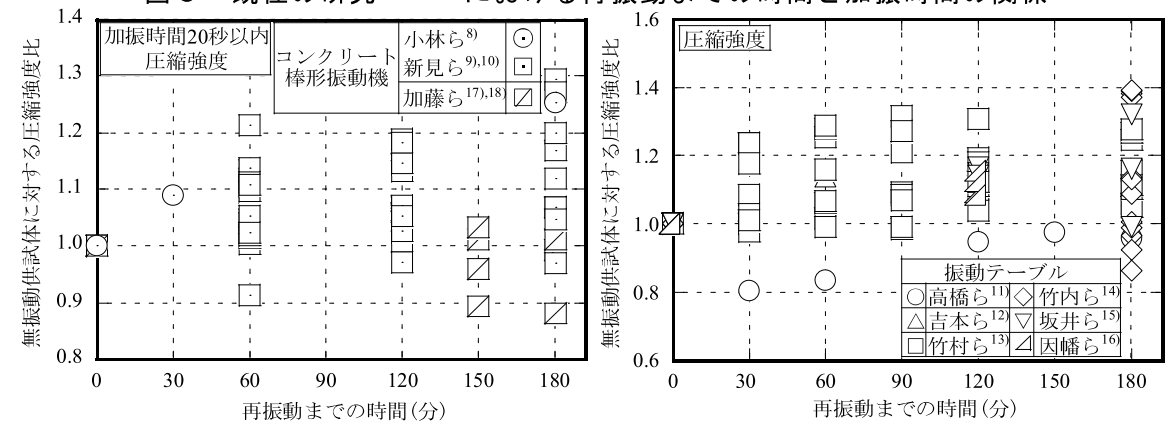

図4再振動までの時間（180 分以内）と無振動供試体に対する圧縮強度比の関係

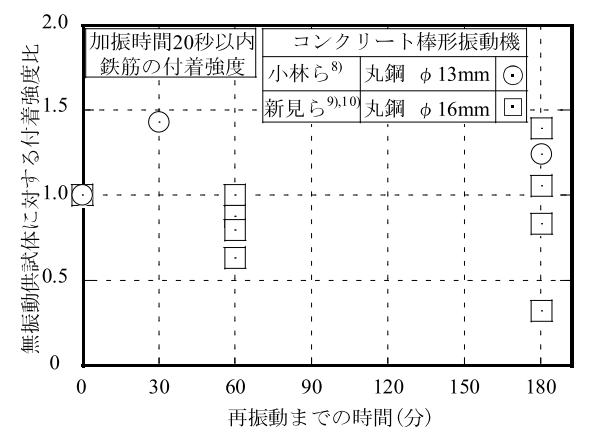

図 5 再振動までの時間（180 分以内）と無振 動供試体に対する付着強度比の関係

動機の場合は加振時間を 20 秒以内のもの について調べた。再振動までの時間 (180 分 以内）と無振動供試体に対する圧縮強度比 の関係を図 4 に示す。コンクリート棒形振 動機を用いて再振動を行なった場合、無振 動供試体に対する圧縮強度比は、小林らの 報告 ${ }^{8)}$ と新見らの報告9)，10) によると再振動 までの時間が経過するにつれて、ほとんど が大きくなる傾向を示している。しかし、 これらの報告 ${ }^{8) ~ 10) ~}$ は水セメント比が比較的 大きく、現在の仕様に対応しているとは言 いがたい。また、振動テーブルを用いて再 振動を行なった場合、無振動供試体に対す る圧縮強度比が再振動までの時間が経過す るにつれて、ほとんどが大きくなる傾向を 示している。そのため、締固めにおける再 振動は、有効な方法という認識が高い。こ の中で、無振動供試体に対する圧縮強度比

度増加すると報告されている。また、わが国において、締固めにお ける再振動に関する多くの報告 ${ }^{8)}$ 18) がされているものの、再振動が コンクリートの圧縮強度に及ぼす影響について検討しているものが ほとんどである。この中で、鉄筋とコンクリートの付着まで行なっ ている報告は極めて少なく、小林らの報告 ${ }^{8)}$ と新見らの報告 ${ }^{9)}$, 10) の みである。しかし、これらの報告は、再振動における丸鋼とコンク リートの付着を検討したものであり、締固めにおける再振動が異形 鉄筋とコンクリートの付着までを検討されていないのが現状であ る。

この再振動の方法は、大きくコンクリート棒形振動機と振動テー ブルに大別できる。既往の研究 ${ }^{8)}$ 18) における再振動までの時間と水 セメント比の関係を図 2 に示寸。また、既往の研究8) 18) における再 振動までの時間と加振時間の関係を図 3 に示寸。これらは、既往の研 究8) 18) において行われた再振動を行う時間, 水セメント比および加 振時間の全てのデータを示しており、再振動を行う時間が最大 720 分までであり, 加振時間が最大 90 秒までが検討されていることが わかる。このように、再振動までの時間および加振時間は、実験的 に行なわれているため、JASS $5{ }^{11}$ における打重㸚時間間隔および 加振時間に比べて過大に設定しているものが多く、実務で行われて いる範囲が強度性状に及ぼす傾向が不明確である。そのため、再振 動までの時間を 180 分以内に限定し、さらに、コンクリート棒形振
が小さくなっているのは、高橋ら ${ }^{11)}$ の報告であり、加振時間が著し く長くなっているためである。

再振動までの時間（180 分以内）と無振動供試体に対する付着強度 比の関係を図 5 に示寸。これは、コンクリート棒形振動機を用いて 再振動を行なった場合のみであり、丸鋼の結果であるが、無振動供 試体に対する付着強度比の傾向は不明である。

そこで、本研究は、打重㸚を行うときの最適な再振動方法を明ら かにするために、再振動までの時間を再振動可能時間の目安となる 150 分までを対象として、再振動の有無が圧縮強度に及ぼす影響を 調べ、さらに再振動における振動距離と振動時間および鉄筋とコン クリート棒形振動機の接触が異形鉄筋の付着性状に及ぼす影響につ いて検討したものである。本論文は、その最初のステップであり、 水セメント比が異なる 2 種類のコンクリートの実験結果からコンク リートの打重ねにおける再振動の方法について検討したものであ る。なお、本研究で取扱う “再振動” は、吉本ら ${ }^{12)}$ のように「再振 動というのは、もともと、打込夕後に振動締固めを行なったコンク リートに対する 2 度目の振動という意味で用いられた言葉である が, 再振動の効果を考えるうえで問題になるのは、その振動が 2 度 目であるという点ではなく、打込夕後、一定時間経過したのちの振 動という点である。」と同様に、打込み後、時間が一定時間経過し たのちの振動を“再振動”として扱っている。 
表 1 コンクリート供試体の作製方法

\begin{tabular}{|c|c|c|c|c|c|c|c|c|c|}
\hline \multirow{2}{*}{$\begin{array}{l}\mathrm{W} / \mathrm{C} \\
(\%)\end{array}$} & \multirow{2}{*}{ 締固め方法 } & \multirow{2}{*}{$\begin{array}{l}\text { 供試体寸法 } \\
\text { (mm) }\end{array}$} & \multicolumn{7}{|c|}{ 練混ぜ開始からの時間(分) } \\
\hline & & & 直後 & & 20 & 45 & 90 & 120 & 150 \\
\hline \multirow[b]{2}{*}{55} & 突き棒 & $\phi 100 \times 200$ & \multicolumn{2}{|l|}{$\begin{array}{l}\text { 練混ぜ直後に試料を採取, 2層詰め } \\
\text { 各層8回突き, 木づちによりたたく }\end{array}$} & \multicolumn{5}{|c|}{$\begin{array}{l}\text { 静置した試料から各々の時間において採取 } \\
\text { 2層詰め, 各層8回突き，木づちによりたたく }\end{array}$} \\
\hline & 振動テーブル & $\phi 100 \times 200$ & $\begin{array}{l}\text { 練混ぜ直後に試料を採取, 2層詰め } \\
\text { 各層8回突き, 木づちによりたたく }\end{array}$ & $\begin{array}{l}15 \text { 秒 } \\
\text { 加振 }\end{array}$ & $\begin{array}{l}15 \text { 秒 } \\
\text { 加振 }\end{array}$ & $\begin{array}{l}15 \text { 秒 } \\
\text { 加振 }\end{array}$ & $\begin{array}{l}15 \text { 秒 } \\
\text { 加振 }\end{array}$ & $\begin{array}{l}15 \text { 秒 } \\
\text { 加振 }\end{array}$ & $\begin{array}{l}\text { 加秒 } \\
\text { 振 }\end{array}$ \\
\hline 35 & $\begin{array}{l}\text { コンクリート } \\
\text { 棒形振動機 }\end{array}$ & $\phi 150 \times 300$ & $\begin{array}{l}\text { 練混ぜ直後に試料を採取, 3層詰め } \\
\text { 各層18回突き, 木つうちによりたたく }\end{array}$ & $\begin{array}{l}15 \text { 秒 } \\
\text { 加振 }\end{array}$ & - & $\begin{array}{l}15 \text { 秒 } \\
\text { 加振 }\end{array}$ & $\begin{array}{l}15 \text { 秒 } \\
\text { 加振 }\end{array}$ & $\begin{array}{l}15 \text { 秒 } \\
\text { 加振 }\end{array}$ & 加振 \\
\hline
\end{tabular}

表 2 コンクリートの使用材料

\begin{tabular}{|c|c|c|}
\hline 材料 & 種類 & 品質 - 性状 · 主成分 \\
\hline セメント & $\begin{array}{l}\text { 普通ポルトランド } \\
\text { セメント }\end{array}$ & $\begin{array}{l}\text { 密度 : } 3.16 \mathrm{~g} / \mathrm{cm}^{3} \\
\text { 比表面積: } 3,300 \mathrm{~cm}^{2} / \mathrm{g}\end{array}$ \\
\hline 水 & 上水道水 & 埼玉県行田市 \\
\hline 細骨材 & $\begin{array}{l}\text { 栃木県産栃木市 } \\
\text { 尻内町産陸砂 }\end{array}$ & $\begin{array}{l}\text { 表乾密度 : } 2.61 \mathrm{~g} / \mathrm{cm}^{3} \\
\text { 粗粒率: } 2.75\end{array}$ \\
\hline 粗骨材 & $\begin{array}{l}\text { 杤木県産栃木市 } \\
\text { 尻内町産石灰岩砕石 }\end{array}$ & $\begin{array}{l}\text { 表乾密度: } 2.61 \mathrm{~g} / \mathrm{cm}^{3} \\
\text { 粗粒率: } 6.64\end{array}$ \\
\hline \multirow{2}{*}{$\begin{array}{l}\text { 化学 } \\
\text { 混和剤 }\end{array}$} & $\mathrm{AE}$ 減水剂 & $\begin{array}{l}\text { リグニンスルホン酸塩 } \\
\text { オキシカルボン酸塩 }\end{array}$ \\
\hline & 高性能AE減水剂 & ポリカルボン酸系化合物 \\
\hline
\end{tabular}

表 3 コンクリートの調合

\begin{tabular}{c|c|c|c|c|c|c|c|c}
\hline \multirow{2}{*}{$\begin{array}{c}\mathrm{W} / \mathrm{C} \\
(\%)\end{array}$} & \multirow{2}{*}{$\begin{array}{c}* 1 \\
(\mathrm{~cm})\end{array}$} & \multirow{2}{*}{$\begin{array}{c}\text { Air } \\
(\%)\end{array}$} & \multirow{2}{*}{$\begin{array}{c}\text { s/a } \\
(\%)\end{array}$} & \multicolumn{5}{|c}{ 単位量 $\left(\mathrm{kg} / \mathrm{m}^{3}\right)$} \\
\cline { 5 - 9 } & & & $\mathrm{W}$ & $\mathrm{C}$ & $\mathrm{S}$ & $\mathrm{G}$ & $\mathrm{Ad}$ \\
\hline 55 & $\mathrm{SL}=18$ & 4.5 & 47.6 & 182 & 331 & 830 & 924 & 3.972 \\
\hline 35 & $\mathrm{SF}=60$ & 4.5 & 50.1 & 170 & 486 & 825 & 831 & 8.262 \\
\hline
\end{tabular}

\section{3．再振動における振動の有無が圧縮強度に及ぼす影響}

\section{1 実験概要}

\section{（1）実験の要因と水準}

再振動における振動の有無が圧縮強度に及ぼす影響を明らかにす るために、再振動の締固め方法および練混ぜ開始からの時間を変え て実験を行った。コンクリート供試体の作製方法を表 1 に示す。コ ンクリートは、練混ぜ直後に採取し、JIS A 1132 : 2006 に準拠し、 突き棒を用いて締固めを行った。加振する時間は、練混ぜ直後, 再 振動として練混ぜ開始後 20,45, 90, 120 および 150 分の 6 水準とし、 振動機に振動テーブルおよび棒形振動機の 2 水準とした。なお、加 振する時間の練混ぜ開始後 20 分は、テーブル振動機の場合のみ 行った。振動テーブルを用いた再振動は、 $\phi 100 \times 200 \mathrm{~mm}$ の鋳物製 型枠に直接、振動テーブル（振動数 $6,000 \mathrm{vpm}$, 周波数 $200 \mathrm{~Hz}$ ）により 再振動を行った。コンクリート棒形振動機を用いた再振動は、 $\phi$ $150 \times 300 \mathrm{~mm}$ の鋳物製型枠に、呼び径 $40 \mathrm{~mm}$ (直径 $43 \mathrm{~m} \mathrm{~m}$, 振動数 $12,000 \mathrm{vpm}$, 振動数 $200 \mathrm{~Hz}$ ) の高周波バイブレータをコンクリートの打 込夕面から約 $280 \mathrm{~mm}$ の深さまで挿入して再振動を行った。なお、い ずれの再振動も加振時間を 15 秒の一定とした。

また、コンクリートを採取する時間ごとの圧縮強度と再振動を 行ったコンクリートの圧縮強度の関係を調べるために、コンクリー 卜を採取する時間を、練混ぜ直後、練混ぜ開始後 $20,45,90,120$ およ び 150 分の 6 水準とし、突き棒を用いて締固めを行った。

コンクリートのブリーディング量はJIS A 1123：2012 に準拠し て測定し、凝結時間はJIS A 1147 ：2007 に準拠して測定した。ま
た、コンクリートの圧縮強度は、JIS A 1108：2006 に準拠して材 齢28 日において測定した。

\section{（2）コンクリートの使用材料および調合}

コンクリートの使用材料を表 2 に示し、コンクリートの調合を表 3 に示寸。ここでは、凝結時間が異なるW/C=55\%およびW/C=35\%の 2 水準とした。また、練混ぜ直後におけるフレッシュコンクリート の目標值は、スランプを $18 \pm 2.5 \mathrm{~cm}$, スランプフローを $60 \pm 10 \mathrm{~cm}$, 空気量を $4.5 \pm 1.5 \%$ とし、目標值を満足するように化学混和剤の 添加量で調節した。

\section{2 実験結果および考察}

\section{（1）フレッシュコンクリートの性状}

練混ぜ開始からの時間とスランプおよびスランプフローの関係を 図 6 に示し、練混ぜ開始からの時間と空気量の関係を図 7 に示す。 ここでは、コンクリートを練混ぜ直後に採取して静置させた試料の 経時変化について検討を行った。なお、試料は、採取直後に再度か くはんして測定を行った。練混ぜ直後におけるスランプ、スランプ フローおよび空気量は、目標值をいずれも満足する結果となった。

\section{（2）ブリーディング量および凝結時間}

練混ぜ開始からの時間とブリーディング量の関係を図 8 に示す。 本実験に用いたコンクリートのブリーディング量は、収縮ひび割れ の抑制のための目標值 ${ }^{19)}$ である $0.3 \mathrm{~cm}^{3} / \mathrm{cm}^{2}$ 以下をいずれも満足する 結果となった。ブリーディング量は、W/C=35\%のとき練混ぜ開始後 300 分程度に、W/C $=55 \%$ のとき練混ぜ開始後 330 分程度に認められ なくなった。また、本実験における試験室の温度が $25^{\circ} \mathrm{C}$ 未満であっ たため、JASS $5^{1)}$ に解説されている外気温が $25^{\circ} \mathrm{C}$ 末満の打重社時間 間隔の限度の目安の 150 分におけるブリーディング量は、W/C=35\% のとき最終的なブリーディング量の約 $80 \%$ であり、W/C=55\%のとき 約 $66 \%$ であった。

練混ぜ開始からの時間と貫入抵抗值の関係を図 9 に示す。始発時 間は、いずれも練混ぜ開始後 150 分以降であり、本実験における再 振動を行う時間は、始発時間前の範囲となった。

\section{(3) 圧縮強度}

練混ぜ開始からの時間と圧縮強度の関係を図 10 に示す。振動 テーブルおよびコンクリート棒形振動機による再振動を行ったコン クリートの圧縮強度は、練混ぜ開始からの時間が長くなると大きく なる傾向を示した。これは、再振動の作業中にブリーディングは目 視により認められなかったものの、コンクリート中の水分の蒸発お よびブリーディングによる見掛けの水セメント比が小さくなったこ と、さらに、再振動により再振動を行う時間までに生じた骨材下面 の空隙、ブリーディング水および水みちが取り除かれたこと到が影 響したためと考えられる。また、練混ぜ直後において、振動テーブ 

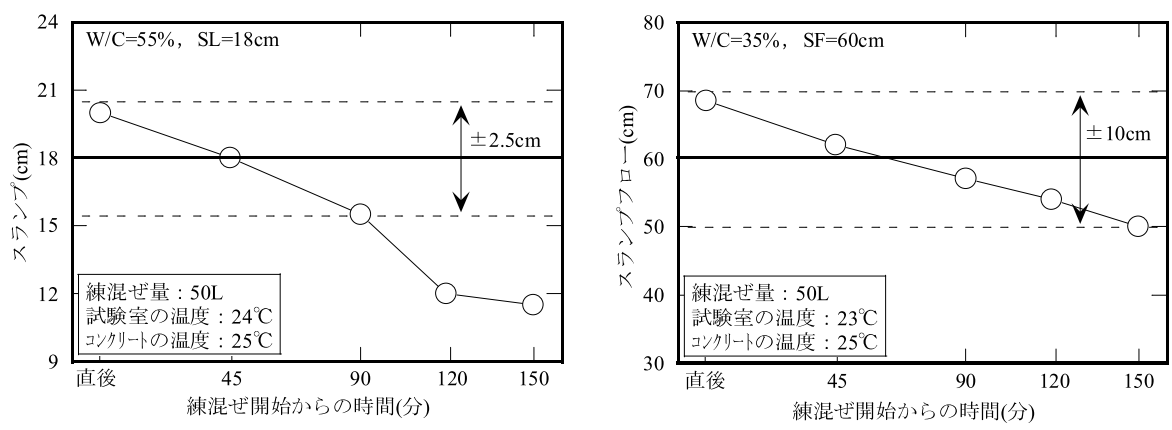

図 6 練混ぜ開始からの時間とスランプおよびスランプフローの関係

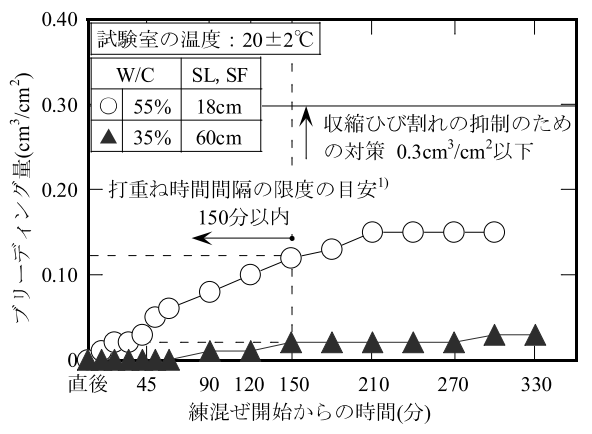

図 8 練混ぜ開始からの時間と ブリーディング量の関係

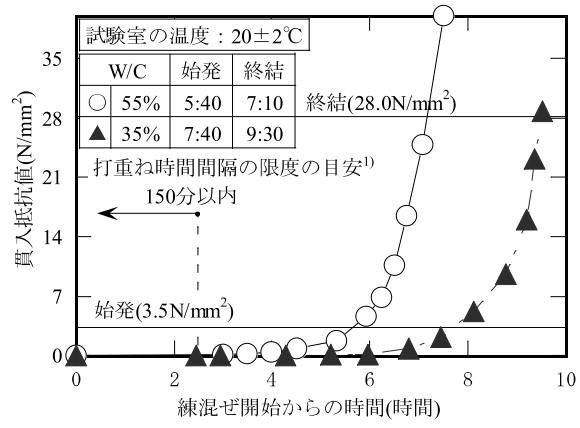

図 9 練混ぜ開始からの時間と貫入抵 抗値の関係

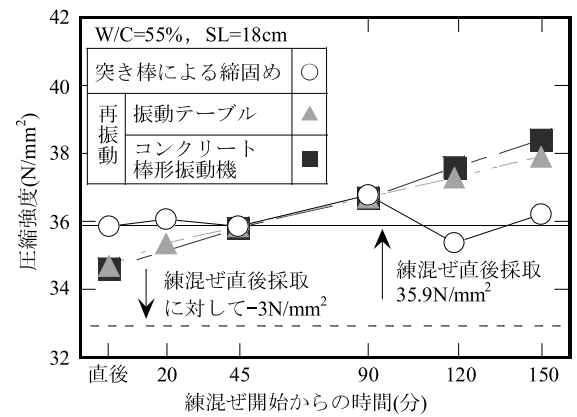

図 10 練混ぜ開始からの時間と圧縮強度の関係
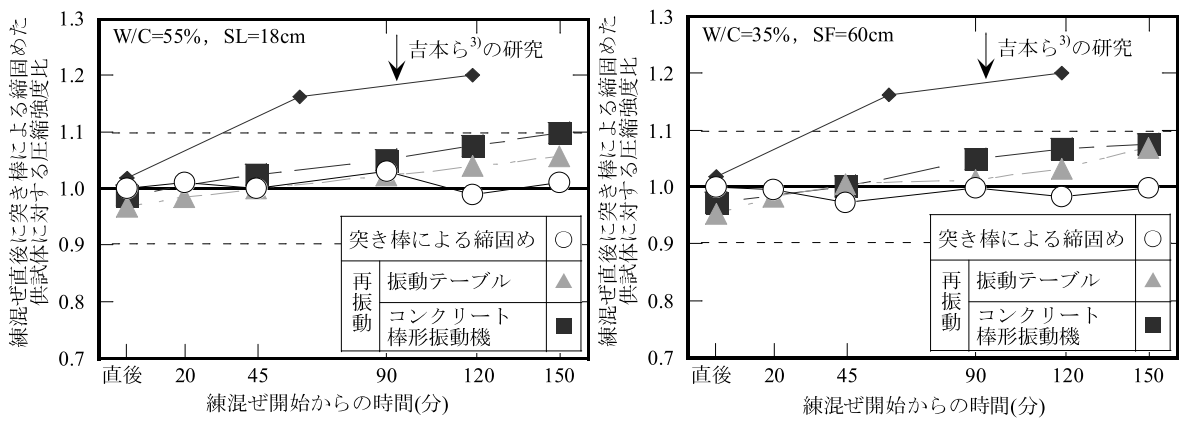

図 11 練混ぜ開始からの時間と練混ぜ直後に採取した 供試体に対する圧縮強度比の関係

あった。しかし、振動テーブルおよびコンクリート棒形振動機によ る再振動を行ったコンクリートの圧縮強度の練混ぜ開始からの時間 が長くなると大きくなる傾向は、吉本ら ${ }^{11)}$ の結果と同様であり、本 実験において $10 \%$ 程度の範囲で大きくなる傾向を示した。

\section{3 実験結果のまとめ}

再振動における振動の有無が圧縮強度に及ぼす影響を調べた結 果、これまでの研究 ${ }^{8)}$ 18) のように再振動可能時間の目安である 150 分程度に再振動を行うと $5 \sim 10 \%$ 程度の圧縮強度が大きくなる傾向 を示した。

もほぼ同等の值を示し、再振動を行ったコンクリートの圧縮強度 は、練混ぜ開始からの時間が長くなると、これより大きくなる傾向 を示した。

練混ぜ開始からの時間と練混ぜ直後に突き棒による締固めを行っ た供試体に対する圧縮強度比 (以下、圧縮強度比という) の関係を図 11 に示寸。なお、図中には、吉本ら ${ }^{12)}$ の結果を比較して示してい る。練混ぜ直後において、振動テーブルおよびコンクリート棒形振 動機による再振動を行ったコンクリートの圧縮強度は、練混ぜ直後 に突き棒による締固めを行ったコンクリートに比べて $5 \%$ 程度以内 で小さくなる傾向を示し、これは、吉本ら ${ }^{12)}$ の結果と異なる傾向で

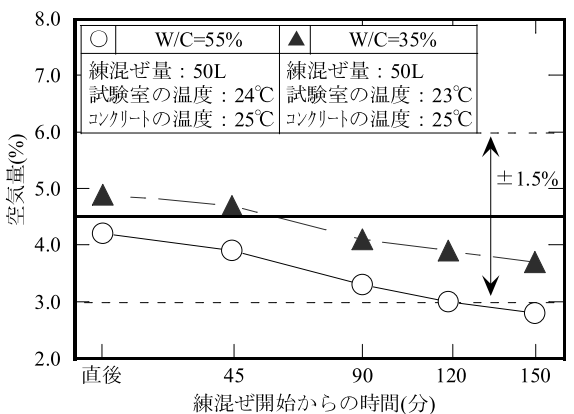

図 7 練混ぜ開始からの時間と 空気量の関係

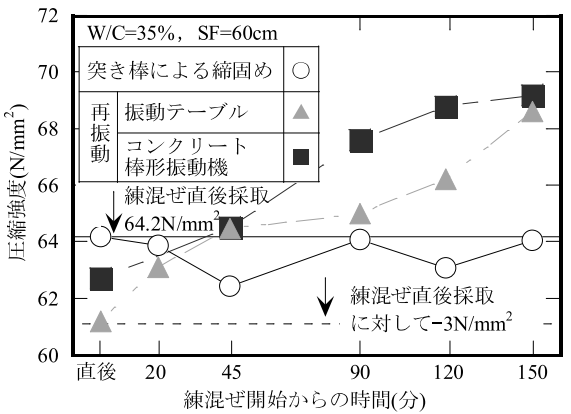

\section{.}


トの打込み方向に対して平行方向および直交方向の 2 水準とした。 加振距離は、平行方向において鉄筋から $100 \mathrm{~mm}$ および $300 \mathrm{~mm}$ の 2 水 準とし、直交方向において鉄筋から $100 \mathrm{~mm}$ の 1 水準とした。また、 練混ぜ開始から再振動までの時間は、練混ぜ直後, 練混ぜ開始後 $45,90,120$ および 150 分とし、いずれも加振時間を 5,15 および 60 秒 の 3 水準とした。

（2）コンクリートの使用材料および調合

コンクリートの使用材料および調合は、3.1(2) と同様のものとし た。

\section{(3) 試験体の概要}

試験体の概要を図 12 に示す。試験体は、鉄筋(D19, SD295A) が埋 込み深さが $150 \mathrm{~mm}$ となるように型枠に設置した。また、コンクリー 卜は練混ぜ直後に打ち込み、締固めを 3.1 (2) と同様なコンクリート 棒形振動機を用いて 5 秒の一定とした。その後、所定の時間におい て、所定の位置にコンクリート棒形振動機を挿入し再振動を行っ た。試験体は、打込みから 48 時間後に脱型し、試験体の寸法が JCI$\mathrm{SPC} 15^{23)}$ と同様に $150 \times 150 \times 150 \mathrm{~mm}$ となるようにコンクリート切断 機を用いて切断し成形した。

\section{（4）付着強度の算出}

付着強度試験は、材齢 28 日において JCI-SPC $15^{23)}$ に準じて行い、

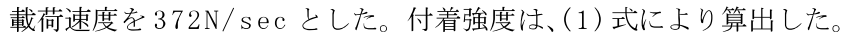

\section{表 4 実験概要}

\begin{tabular}{|c|c|c|c|c|c|c|c|}
\hline \multirow{3}{*}{$\begin{array}{l}\text { W/C } \\
(\%)\end{array}$} & \multirow{3}{*}{$\begin{array}{l}\text { 鉄筋の } \\
\text { 方向 }\end{array}$} & \multirow{3}{*}{$\begin{array}{l}\text { 加振 } \\
\text { 距離 } \\
(\mathrm{mm})\end{array}$} & \multicolumn{5}{|c|}{ 練混ぜ開始から再振動までの時間(分) } \\
\hline & & & 直後 & 45 & 90 & 120 & 150 \\
\hline & & & \multicolumn{5}{|c|}{ 加振時間(秒) } \\
\hline \multirow{6}{*}{55} & \multirow{3}{*}{ 平行 } & 100 & 5 & 5 & 5 & 5 & 5 \\
\hline & & & 15 & 15 & 15 & 15 & 15 \\
\hline & & 300 & 60 & 60 & 60 & 60 & 60 \\
\hline & \multirow{3}{*}{ 直交 } & \multirow{3}{*}{100} & 5 & 5 & 5 & 5 & 5 \\
\hline & & & 15 & 15 & 15 & 15 & 15 \\
\hline & & & 60 & 60 & 60 & 60 & 60 \\
\hline
\end{tabular}

$$
\tau=\frac{P_{\max }}{\phi \cdot L}
$$

ここに、 $\tau:$ 付着強度 $\left(\mathrm{N} / \mathrm{mm}^{2}\right)$

$$
\begin{aligned}
& \mathrm{P}_{\max }: \text { 最大引張荷重 }(\mathrm{N}) \\
& \mathrm{L}: \text { 鉄筋の埋込み長さ }(\mathrm{mm}) \\
& \phi: \text { 鉄筋周長 }(\mathrm{mm})
\end{aligned}
$$

\section{2 試験結果および考察}

練混ぜ開始から再振動までの時間と付着強度の関係を図 13 に示 す。付着強度は、練混ぜ開始から再振動までの時間が長くなるとい ずれも大きくなる傾向を示した。これは、3.2(3)の圧縮強度と同様 な理由と考えられ、コンクリート中の水分の蒸発およびブリーディ ングによる見掛けの水セメント比が小さくなったこと、再振動まで に発生した鉄筋周囲の空隙, ブリーディング水および水みちが再振 動によって取り除かれたこと ${ }^{20)}$ が影響したためと考えられる。ま た、打込夕方向に対寸る鉄筋の方向について、直交方向の付着強度 は、平行方向に比べて小さくなる傾向を示し、練混ぜ開始から再振

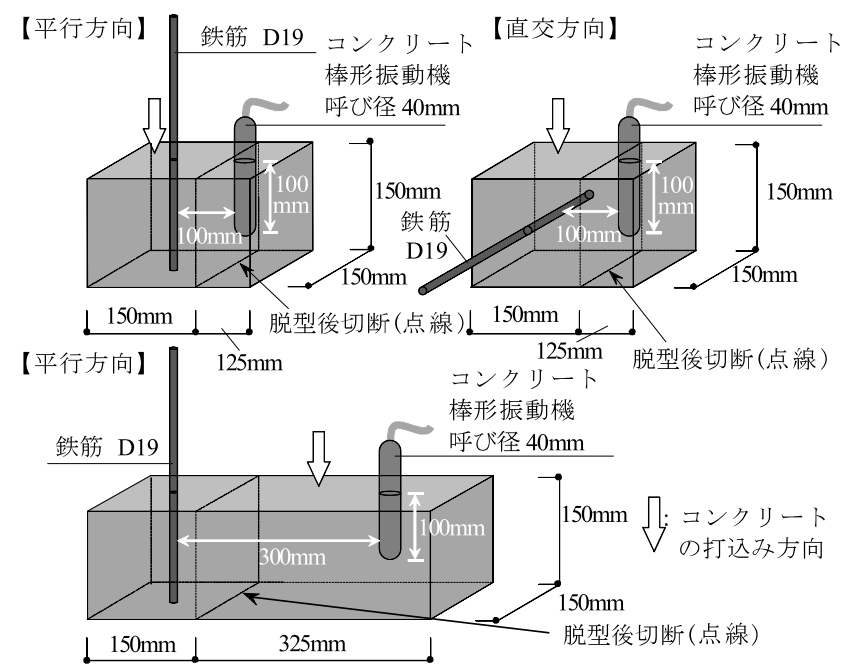

図 12 試験体の概要

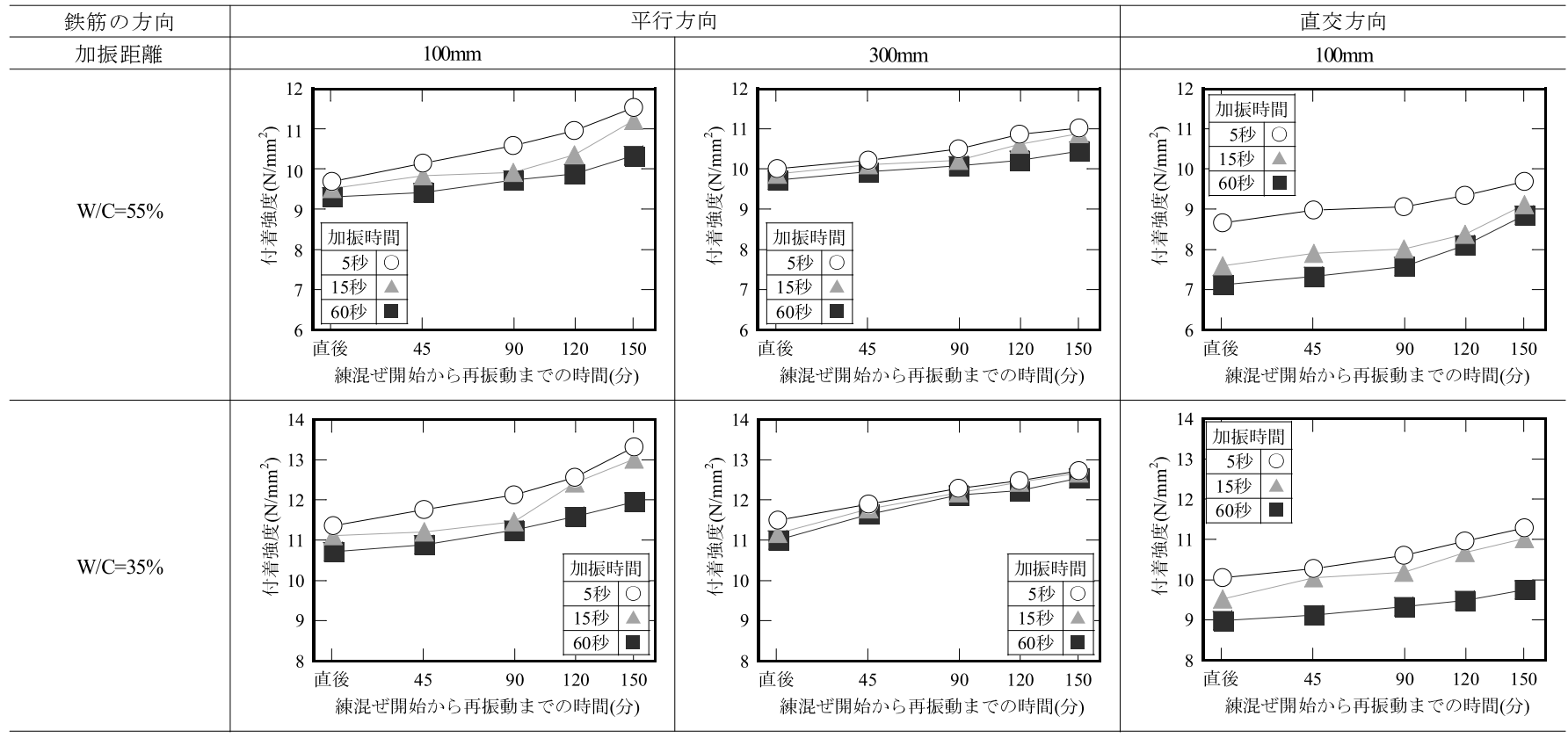

図 13 練混ぜ開始から再振動までの時間と付着強度の関係 


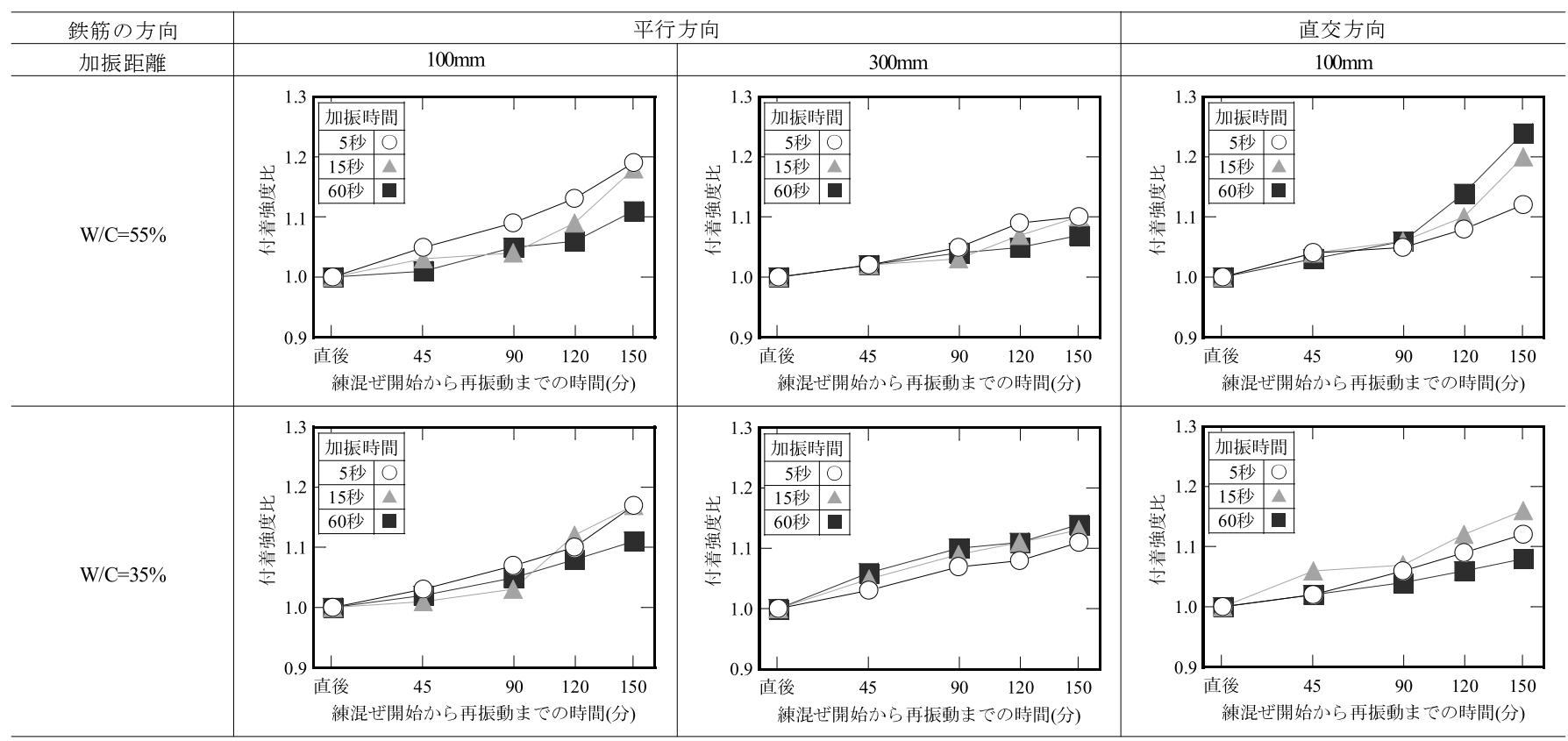

図 14 練混ぜ開始から再振動までの時間と練混ぜ直後に再振動を行った供試体に対する付着強度比の関係

動までの時間が同一の付着強度は、加振時間が長くなると小さくな る傾向を示した。また、直交方向の付着強度の方が加振時間が長く なると小さくなる傾向を顕著に示した。これは、打込み方向に対し て直交方向に設置された鉄筋の下面に、コンクリートの沈下および 気泡などによる空隙, ブリーディング水および水みちによる脆弱部 の総面積が、平行方向の鉄筋に比べて大きくなるためと考えられ る。さらに、過度な振動により、試験体内部のコンクリートが不均 一になったこと ${ }^{24)}$ が付着強度に影響しているものと考えられる。

打込み方向に対する鉄筋の方向が平行の場合、練混ぜ直後に対す る付着強度の変化量は、加振距離 $100 \mathrm{~mm}$ の付着強度の变化量が加振 距離 $300 \mathrm{~mm}$ に比べて大きくなる傾向を示した。これは、コンクリー 卜棒形振動機による振動の伝搬距離が影響したためと考えられる。 練混ぜ開始から再振動までの時間と練混ぜ直後に再振動を行った 供試体に対する付着強度比（以下、付着強度比という）の関係を図 14 に示寸。付着強度比は、3.2(3) の圧縮強度と同様に、練混ぜ開始 から再振動までの時間が長くなるほど、いずれも大きくなる傾向を 示した。また、付着強度比は、打込み方向に対する鉄筋の方向が平 行方向の場合、練混ぜ開始から再振動までの時間 150 分のとき、ば らつきがあるものの 1.1 程度を超えるものもあり、3.2(3)の圧縮強 度より若干大きくなる傾向を示した。加振距離が $300 \mathrm{~m} \mathrm{~m}$ の場合、 $W / C=55 \%$ のとき、付着強度比は、加振時間が短いほど大きくなる傾 向を示し、W/C=35\%のとき、この傾向と逆の傾向を示した。これは、 W/C が小さく、セメント量が多い高強度コンクリートで加振距離が 長い場合、加振時間を長くしなければ付着強度比が向上しないこと を示唆していると考えられる。また、打込み方向に対する鉄筋の方 向が直交方向の場合、加振時間による付着強度比は明確な傾向が見 られなかったが、これは、練混ぜ開始直後の結果のばらつきの影響 によるものと考えられる。

\section{3 実験結果のまとめ}

再振動における振動距離と振動時間が異形鉄筋の付着強度に及ぼ 寸影響を再振動可能時間の目安である 150 分程度について調べた結
表 5 実験概 要

\begin{tabular}{|c|c|c|c|c|c|c|}
\hline \multirow{2}{*}{$\begin{array}{l}\mathrm{W} / \mathrm{C} \\
(\%)\end{array}$} & \multirow{2}{*}{$\begin{array}{l}\text { 鉄筋の } \\
\text { 方向 }\end{array}$} & \multicolumn{5}{|c|}{$\begin{array}{l}\text { 再振動におけるコンクリート } \\
\text { 棒形振動機と接触開始時間(分) }\end{array}$} \\
\hline & & 直後 & 45 & 90 & 120 & 150 \\
\hline \multirow{2}{*}{55} & 平行 & $\begin{array}{c}5 \\
15 \\
30 \\
90 \\
\end{array}$ & $\begin{array}{c}5 \\
15 \\
30\end{array}$ & $\begin{array}{c}5 \\
15 \\
30 \\
90 \\
\end{array}$ & $\begin{array}{c}5 \\
15 \\
30\end{array}$ & $\begin{array}{c}5 \\
15 \\
30 \\
90 \\
\end{array}$ \\
\hline & 直交 & $\begin{array}{c}5 \\
15 \\
30\end{array}$ & $\begin{array}{c}5 \\
15 \\
30\end{array}$ & $\begin{array}{c}5 \\
15 \\
30\end{array}$ & $\begin{array}{c}5 \\
15 \\
30\end{array}$ & $\begin{array}{c}5 \\
15 \\
30\end{array}$ \\
\hline 35 & 平行 & $\begin{array}{c}5 \\
30 \\
90\end{array}$ & - & $\begin{array}{c}5 \\
30 \\
90\end{array}$ & - & $\begin{array}{c}5 \\
30 \\
90\end{array}$ \\
\hline
\end{tabular}

※試験体数:各3体

果、次のことがいえる。

（1）付着強度は、練混ぜ開始から再振動までの時間が長くなると大 きくなる傾向を示し、付着強度比が 1.1 程度となった。

（2）打込从方向に対寸る鉄筋の方向について、直交方向の付着強度 は、平行方向に比べて小さくなる傾向を示し、加振時間が長く なると小さくなる傾向を示した。

（3）付着強度比は、W/C=35\%のとき加振距離 $300 \mathrm{~mm}$ の場合に、加振 時間が長くなると大きくなる傾向を示した。

\section{5. 再振動における鉄筋とコンクリート棒形振動機の接触が異形} 鉄筋の付着性状に及ぼす影響

\section{1 実験概要}

\section{（1）実験の要因と水準}

再振動における鉄筋とコンクリート棒形振動機の接触が鉄筋の付 着性状に及ぼす影響を明らかにするために、打込み方向に対する鉄 筋の方向，鉄筋とコンクリート棒形振動機の接触時間および接触開 始時間を変えて実験を行った。実験概要を表 5 に示す。鉄筋の方向 は、コンクリートの打込み方向に対して平行方向および直交方向 の 2 水準とした。鉄筋とコンクリート棒形振動機の接触時間は、表 
5 に示すような水準として最大 90 秒とした。また、鉄筋とコンク リート棒形振動機の接触開始時間は、3.1 (1) と 4.1(1) と同様とし た。

\section{（2）コンクリートの使用材料および調合}

コンクリートの使用材料および調合は、3.1 (2) と同様のものとし た。

\section{(3) 試験体の概要} 込み長さを $150 \mathrm{~mm}$ で型枠に設置し、試験体の寸法は JCI-SPC $15^{23)}$ と同 様にW150×H150 ×D $150 \mathrm{~mm}$ とした。無接触を含む全ての試験体への コンクリートの打込みは、練上り直後に行い、鉄筋を設置した後に 一層に打ち込んでから突き棒で 20 回突き、型枠の外側を木桘で 10 回吒いた。また、鉄筋とコンクリート棒形振動機の接触は、図 15 のようにの供試体上面から $200 \mathrm{~mm}$ の位置で鉄筋へ直角に行った。鉄 筋とコンクリート棒形振動機の固定は、振動のみを鉄筋に伝播させ るためゴムチューブを巻き付けた。なお、支持台は、正確な配筋を 想定した鉄筋の摇れを抑えるもので、鉄筋の直交および平行を確保 寸るために設置し、鉄筋は 2 点で固定した。コンクリート棒形振動 機は、3.1（1）と同様なものを用いた。

\section{(4) 付着強度の算出}

付着強度試験および付着強度の算出は、4.1（4）と同様とし、材齢

\section{2 結果および考察}

接触開始時間と付着強度の関係を図 16 に示寸。付着強度は、鉄 筋とコンクリート棒形振動機の接触開始時間が遅くなるといずれも 小さくなる傾向を示し、接触時間が長くなるとその傾向が顕著と なった。これは、鉄筋とコンクリート棒形振動機の接触により鉄筋

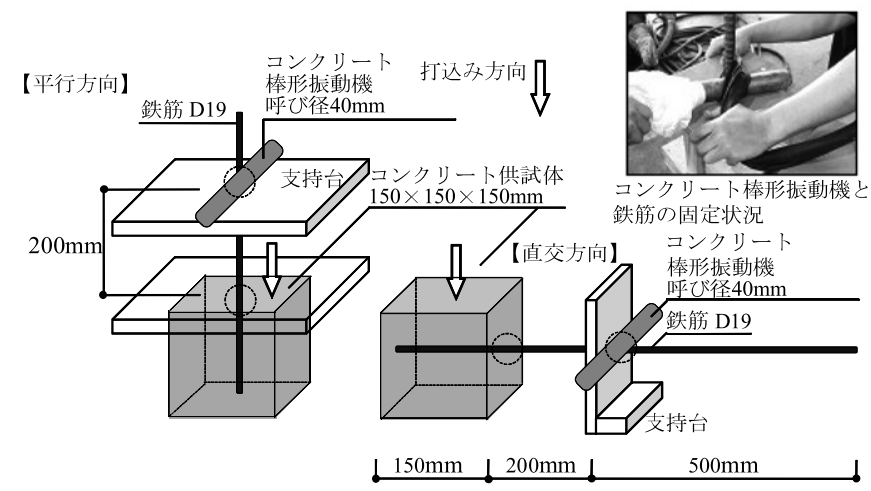

図 15 試験体の概要
試験体の概要を図 15 に示寸。試験体は、鉄筋(D 19、SD295A)の埋 28 日において行った。

が振動して鉄筋の周囲において空隙が発生し、付着が脆弱になった ためと考えられる。この傾向は、これまでの前章 3 . および前章 4 . のように練混ぜ開始から再振動までの時間が長くなると、強度に有 利に働いていた傾向と大きく異なる傾向を示した。また、接触開始 時間が早く、接触時間が短い場合の付着強度は、無接触よりも大き くなる傾向を示した。このことは、コンクリートハンドブック ${ }^{25)} に$ も記述されているが、コンクリート棒形振動機の振動が鉄筋を伝搬 して間接的にコンクリートを再振動させたためと考えられる。接触 開始時間が遅く、接触時間が長い場合の付着強度は、無接触よりも 小さくなるものもあった。すなわち、鉄筋とコンクリート棒形振動 機の接触が接触開始時間 90 分を超える場合、接触時間により付着 強度を低下させる危険性を示唆している。

直交方向の付着強度は、同一の接触時間のとき平行方向に比べて 小さくなる傾向となった。これは前述したように、コンクリート振 動機の振動が鉄筋を伝搬して間接的にコンクリートを再振動させた ためであり、直接的に締固めを行った場合と異なり、鉄筋の脆弱部 の面積が大きいため平行方向のように付着強度の向上にまではつな がらなかったと考える。また、水セメント比の違いによる傾向は、 見られなかった。

\section{3 実験結果のまとめ}

再振動における鉄筋とコンクリート棒形振動機の接触が異形鉄筋 の付着性状に及ぼす影響を再振動可能時間の目安である 150 分程度 について調べた結果、次のことがいえる。

（1）付着強度は、鉄筋とコンクリート振動機の接触開始時間が遅く なるといずれも小さくなる傾向を示し、接触時間が長くなると その傾向が顥著となった。

(2) 接触開始時間が早く、接触時間が短い場合の付着強度は、無接 触よりも大きくなる傾向を示した。

(3) 接触開始時間が遅く、接触時間が長い場合の付着強度は、無接 触よりも小さくなる傾向を示した。

(4) 直交方向の付着強度は、平行方向に比べて小さい傾向となった。 今回の実験において鉄筋とコンクリート棒形振動機の接触距離を $200 \mathrm{~mm}$ と一定にしているが、今後はこの影響について検討しなけれ ばならない。

\section{6. 鉄筋とコンクリート棒形振動機の接触を考慮したコンクリー トの締固めにおける再振動に関する一考察}

これまでに再振動における振動の有無が圧縮強度に及ぼす影響, 再振動における振動距離と振動時間が異形鉄筋の付着性状に及ぼす

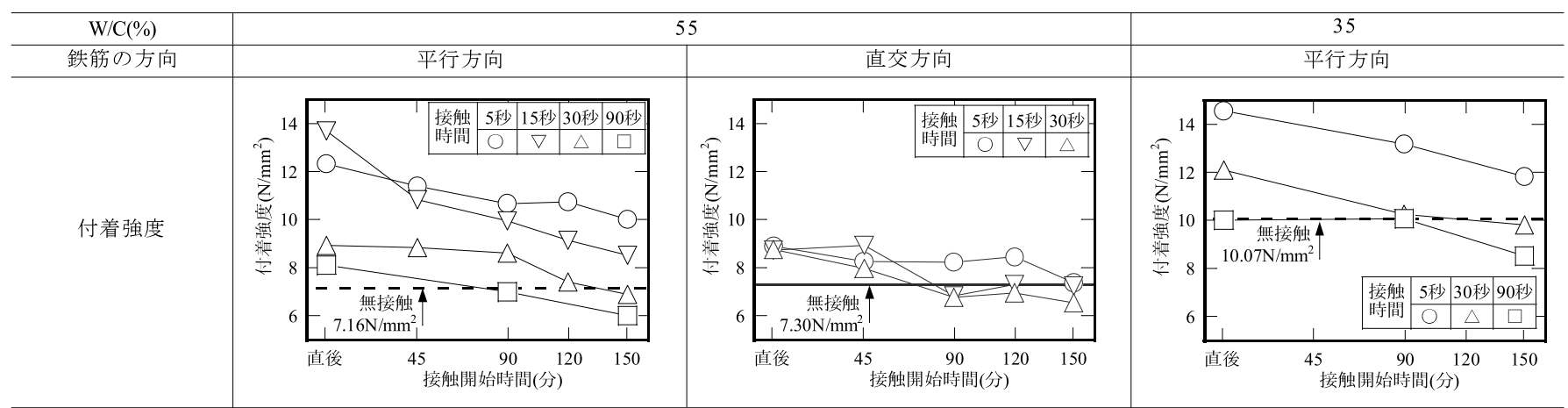


表 6 コンクリートの締固めにおける再振動が構造体に及ぼす傾向

\begin{tabular}{|c|c|}
\hline 影響要因 & 構造体に及ぼす傾向 \\
\hline 振動の有無が圧縮強度に及ぼす影響 & •練混ぜ直後から再振動までの時間および振動時間が長くなると圧縮強度が大きくなる傾向 \\
\hline $\begin{array}{l}\text { 振動距離と振動時間が異形鉄筋の付着性状 } \\
\text { に及ぼす影響 }\end{array}$ & 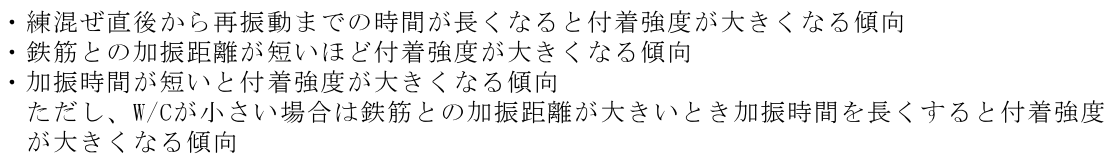 \\
\hline $\begin{array}{l}\text { 鉄筋とコンクリート棒形振動機の接触が異形 } \\
\text { 鉄筋の付着強度に及ぼす影響 }\end{array}$ & $\begin{array}{l}\text { •練混ぜ直後から再振動までの時間が長くなると付着強度が小さくなる傾向 } \\
\text { ・練混ぜ直後から再振動までの時間が短いとき鉄筋とコンクリ棒形振動機の接触時間が } \\
\text { 短いと付着強度が小さななる傾向 } \\
\text { •練混ぜ直後から再振動までの時間が長いとき鉄筋とコンクリート棒形振動機の接触時間が } \\
\text { 長くなると付着強度が小さくなる傾向 }\end{array}$ \\
\hline
\end{tabular}

影響および再振動における鉄筋とコンクリート棒形振動機の接触が 異形鉄筋の付着性状に及ぼす影響について検討した結果からコンク リートの締固めにおける再振動が構造体に及ぼす傾向をまとめると 表 6 のようになる。このことから、JASS $55^{1)}$ において打重ね時間間 隔の限度は、「一律に定めることはできないが、一般的には、外気 温が $25^{\circ} \mathrm{C}$ 未満のときは 150 分、 $25^{\circ} \mathrm{C}$ 以上のときは 120 分を目安とし、 先に打ち込んだコンクリートの再振動可能時間以内とする。」と解 説されている点に補足するのであれば、「コンクリートの締固めに おける再振動を行なう時期は再振動可能時間で遅い方が良い。ま た、この場合、鉄筋とコンクリート棒形振動機はできるだけ接触さ せないようにし、やむを得ず接触したときは、できるだけこの接触 時間を短くする。」ことが考えられる。

もう 1 点として、「振動機の先端は、鉄骨・鉄筋・埋込み配管 · 金物・型枠などになるべく接触させない。」と解説されている点に 補足するのであれば、「鉄筋とコンクリート棒形振動機の接触は、 鉄筋の位置が確実に固定されている場合、再振動時間が短いとき、 鉄筋と付着性状に有利に働くため、再振動を行なう時期はできるだ け早い時期に行うと良い。」ことが考えられる。

以上のように、鉄筋とコンクリート棒形振動機の接触がコンク リートの締固めにおける再振動の施工要領について考察した。この ことは、あくまで既往の研究と本実験結果から考えたものであり、 今後は、コンクリートの種類, 凝結速度, 温度および鉄筋とコンク リート棒形振動機との距離などを検討しなければならない。

\section{謝辞}

本研究では、故毛見虎雄博士 (前足利工業大学工学部建築学科教 授）より示唆に富むご助言を賜りました。また、実験およびデータ 整理に際して坂本英之君（現；大林組）をはじめとした、日本大学 理工学部建築学科およびものつくり大学技能工芸学部建設学科の学 生より多大なご協力を頂きました。ここに付記して深謝申し上げま す。

\section{参考文献}

1) 日本建築学会 : 建築工事標準仕様書・同解説 JASS 5 鉄筋コンクリート工 事, 2009.2

2) 土木学会 : 2007 年制定コンクリート標準示方書 [施工編 : 施工標準 $] 2007$ 年 制定, 2012.12

3 ) 坂本英之, 中田善久, 大塚秀三, 毛見虎雄 : 締固めにおける棒形振動機と鉄 筋の接触がコンクリートと鉄筋の付着強度に及ぼす影響, コンクリート工学 年次論文集, Vol. 33, No. 1, pp. 383-388, 2011
4) 坂本英之, 中田善久, 大塚秀三, 毛見虎雄: 締固め作業によるコンクリート 之鉄筋の付着強度比に関する一考察，日本コンクリート工学会コンクリート と補強材の付着举動構成則に関するシンポジウム論文集，pp. 289-294，2011.9

5 ) JIS A 5308 : 2009 レディーミクストコンクリート, 2009

6) 毛見虎雄 : コンクリートの施工法一その移り変り一(その12) 建築物におけ るコンクリート施工計画の移り変り, コンクリート工学, Vol. 19, №. 6, pp. 60-68, 1981

7) Vollick C. A:Effects of Revibrating Concrete, Jour. A. C. I “5803”, pp. 721$732, \quad 1958$

8) 小林制，金子操：鉄筋を利用した再振動工法に関する研究 コンクリート付 着強度に関する研究, 日本建築学会論文報告集, 第63号, pp. 233-236, 1959.10

9 ) 新見芳男 : コンクリートの再振動之鉄筋附着強度 第 1 報, 日本建築学会関 東支部，第 27 回研究発表会, pp. 97-100, 1960.1

10) 新見芳男：コンクリートの再振動々鉄筋附着強度 第 2 報, 日本建築学会関 東支部，第 28 回研究発表会，pp. 41-44，1960.6

11) 高橋久雄, 中根淳: コンクリートの締固姓状に関する研究: 第 5 報・再振動 および長時間振動の影響, 日本建築学会大会学術講演梗概集, pp. 85-86, 1970.9

12) 吉本彰, 白上博明: 再振動コンクリートにおける強度增大の機構, セメント・ コンクリート, No. 365，pp. 8-14，1977.7

13)竹村和夫, 阿部康俱 : 再振動締固めによる強度の增進効果について, セメン 卜技術年報，Vol. 39，pp. 249-252，1985.2

14)竹内資雄, 渡辺健治, 小野博宣, 大津武 : 打設後の再振動がコンクリートの 強度発現に及ぼす影響, 日本建築学会東海支部研究報告集, 第 41 号, pp. 1720, 2003. 2

15)坂井映二, 三上貴正 : 圧縮强度からみた再振動締固めの有効性の基礎的考察, 日本建築学会大会学術講演梗概集, A-1 分冊, pp. 1199-1200, 1993.7

16)因幡芳樹, 金子樹, 守屋健一, 渡边創一郎 : エコセメントを用いたコンクリー 卜の打重衩時間間隔に関寸る実験的研究その 3 打重社部の付着強度, 日本 建築学会大会学術講演梗概集, A-1 分冊, pp. 439-440, 2007.7

17)加藤淳司, 水田実 : コンクリートの再振動締固めの実施工適用性に関する研 究 その 1 適用範囲、施工性、実施時期判断基準、得られる効果についての 室内実験結果, 日本建築学会大会学術講演梗概集, A-1 分冊, pp. 673-674, 2010.9

18)水田実, 加藤淳司 : コンクリートの再振動締固めの実施工適用性に関する研 究 その 2 壁状模擬試験体による再振動締固効果等の確認実験結果, 日本 建築学会大会学術講演梗概集, A-1 分冊, pp. 675-676, 2010.9

19）日本建築学会 : 鉄筋コンクリート構造物の収縮ひび割れ制御設計・・施工指針 (案) ・同解説, 2006.2

20) 技報堂出版 : ネビルのコンクリートバイブル，pp. 295-296，2006. 2

21) 松本雅之, 桝田佳寛, 阿部道彦, 高塩美佐子, 新屋栄一: 高強度コンクリー 卜の圧縮強度試験方法の標準化に関する研究 その 6 型枠の種頪, 締固め方 法の影響, 日本建築学会大会学術講演梗概集, A-1 分冊, pp. 1252-1253, 1990.10

22) 日本建築学会 : 建築工事標準仕様書・同解説 JASS 5 鉄筋コンクリート工 事, 1997.1

23) (社) 日本コンクリート工学協会 : JCI 規準集 2004 (1997 2002 年度); (15) ポ リマーセメントモルタルの鉄筋に対する付着強さ試験方法(案), pp. 254-255, 2004

24) 張文博, 李柱国, 李潔勇, 吉村貢 : 硬化コンクリートの力学性能に及ぼす振 動締固めの影響に関する実験的考察，日本建築学会中国支部研究報告集，第 33 巻, pp. 1-4, 2010. 3

25)吉田徳次郎 : コンクリートハンドブック , p. 116, 1949 


\title{
INVESTIGATION OF REVIBRATING CONDITIONS WHEN DEFORMED BARS ARE IN CONTACT WITH INTERNAL VIBRATOR
}

\author{
Yoshihisa NAKATA*, Shuzo OTSUKA**, Atsunori MIYATA*** \\ and Naohiro NIITUMA****
}

\author{
* Prof., Dept. of Architecture, College of Science and Technology, Nihon University, Dr. Eng. \\ ** Assoc. Prof., Dept. of Building Technologists, Monotsukuri Institute of Technologists, Dr. Eng. \\ *** Research Assist., Dept. of Architecture, College of Science and Technology, Nihon University, M. Eng. \\ **** NIIDUMA KOGYO CO., LTD.
}

This paper deals with the revibrating conditions for concrete compaction taking account of contact between steel deformed bar and internal vibrator. Timing of revibrating applicable to the consolidated fresh concrete is limited to avoid unexpected cold joint as specified in JASS 5. In general, timing from mixing to revibrating is recommended to be as late as possible.

Compaction conditions with a rod vibrator commented by JASS 5 are that the rod vibrator should not be in contact with the steel, embedded pipes, metal fastenings and formworks. This is to avoid unintended rearrangement of reinforcements and formworks while in reality, reinforcing steel arrangements are particularly crowded at relatively small elements such as walls and beams and the contact between vibrator and the reinforcing steel is unavoidable during construction. Particularly, when revibration is performed at the joint of concretes with different placement times, the contact becomes tighter and unfortunately, existing studies dealing with the effects of the contact on the quality of concrete in structures are very few.

So this study aimed to explain appropriate conditions of revibrating applicable to the consolidated fresh concrete taking account of contact between steel deformed bar and internal vibrator. In this experiment, the effects of revibrating on compressive strength and bond strength were investigated. Parameters included difference in timing from mixing to revibrating, duration of revibrating, distance of revibrating point and duration of contant between steel deformed bar and internal vibrator.

The main contents of this paper are as follows : (1) Influence of revibrating on compressive strength. (2) Influence of distance of revibrating point and duration of revibrating on bond behavior. (3) Influence of contact between steel deformed bar and internal vibrator in revibrating on bond behavior.

The major findings of this study can be summarized as follows.

(1) Compressive strength and bond strength of the revibrated specimens tended to increase when timing from mixing to revibrating increased.

(2) Bond strength of the revibrated specimens tended to decrease when duration of revibrating increased.

(3) Bond strength perpendicular to the placing direction was smaller than that parallel to the placing direction.

(4) Bond strength of revibrated specimens subjected to the contact between steel deformed bar and internal vibrator tended to decrease when timing from mixing to revibrating and duration of contact increased.

This paper showed appropriate conditions of revibrating when applied to the consolidated fresh concrete on the basis of experimental results. If it can be possible to compensate for JASS 5, timing from mixing to revibrating should be as late as possible. Also in this case, duration of contact of between steel deformed bar and internal vibrator should be as short as possible. If steel deformed bars are sufficiently fixed, timing for mixing to revibrating should be as fast as possible because the contact between steel deformed bar and internal vibrator may pose favorable effects on the bond behavior.

Revibration compaction conditions, when a rod vibrator is in contact with the steel reinforcements, were discussed as above. The conclusions are derived from the limited data from the present experiments and existing literatures. Hence further study is needed regarding the type of concrete, setting speed, ambient temperature and distance from vibrator and reinforcing steel. 